\title{
The Relationship between Employee Well-Being, Burnout and Perceived Organizational Support in Healthcare Professionals
}

\author{
Nursel AYDINTUG MYRVANG ${ }^{1}$
}

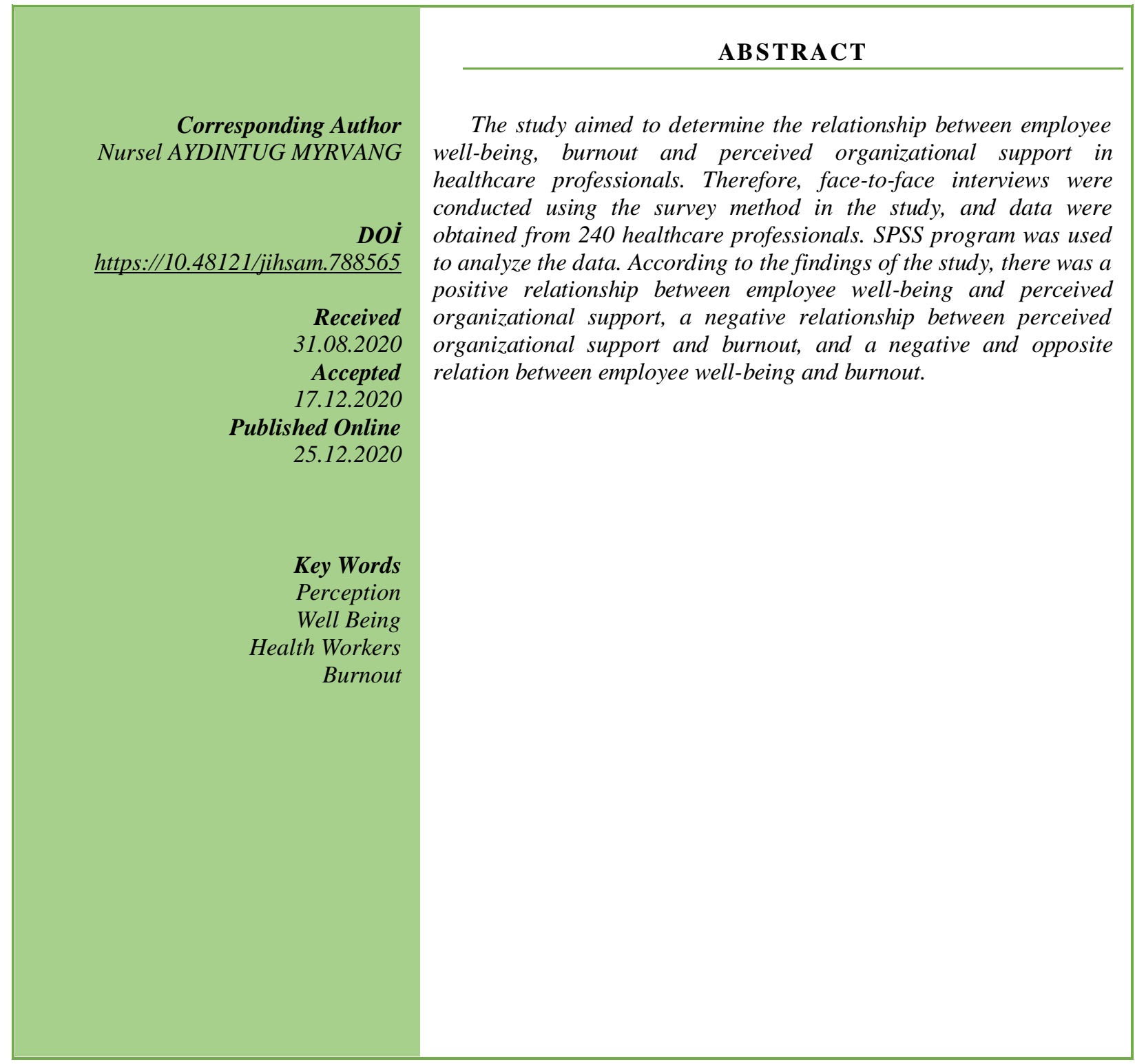




\section{INTRODUCTION}

A healthcare professional is someone who offers services to patients in need. Therefore, the need for healthcare professionals is increasing day by day. An increase in the need for healthcare professionals brings along a heavy workload with it. Therefore, healthcare professionals may experience burnout syndrome. For healthcare professionals not to experience burnout syndrome, the employee must be in a state of wellbeing, which is expressed as the individual's feeling himself/herself good in life, in the workplace and psychologically. Employee well-being is not just a situation that occurs when an individual feels physically well. It is an individual's feeling good both in his/her social life, in business life and psychologically (Short, 2018). Institutions need to realize that there is more to employee well-being than mere physical condition. Employee well-being is also related to the psychological state of the individual and his/her situation in the workplace. Institutions need to look at their employees from a holistic perspective. This is a condition that can only be accomplished in employee-centered organizations. It is known that in employee-centered institutions, employee well-being is higher. Employees working in employee-centered organizations also do not suffer from burnout syndrome (Martic, 2020).

Burnout is a term that originated in the 1961 British writer Graham Greene's novel "A Burnout Case,' which deals with the work of an architect to escape to Africa and begin his life in the forest due to psychological distress in his residence. Then, in the 1970s, it became a concept used to describe the psychological crises that took place in working life in America (Keles and Goktepe, 2020: 857).Besides, the definition of burnout was first discussed in an article written by Freudenberger, who performed the first clinical case studies in 1974, on adverse circumstances in business life, and was published in this article (Balcıoğlu et al., 2008: 101). Christina Maslach has been seen as the leading researcher for burnout. While Maslach is the creator of the 'Maslach Burnout Inventory,' which is the most commonly known burnout concept, he describes burnout as the reactions of employees in face-to-face relationships to chronic stress factors that cause material and spiritual wear. Maslack has treated burnout in three different dimensions as emotional exhaustion, desensitization, and the level of personal success(Ali, 2020: 21)

Burnout has a major problem for healthcare professionals. A healthcare professional with burnout syndrome may not be able to provide adequate services to people in need of healthcare professionals. This situation may have negative consequences for both parties. Healthcare workers should also be assisted by the company they are in and staff should have a sense of organizational support. Perception is a set of processes that combine and understand or interpret the information gained from individuals 'senses and their environment and varies according to individuals' focal points (Bacaksı, 2016). The positive impact they provide to their organizations perceived organizational support individuals with their performances, to be given to employees valued by the organization and the individual employee implies being aware of the approach of the organization (Demirel, 2013; Kaplan and Advice; 2012).

Employees knowing that their behavior is supported by the organization, that their performance will be rewarded is being thought that the concept of perceived organizational support, expressed as knowing that the values they add to the institution will be given importance and that the existence of the organization is with them so that they feel safe (Özdevecioğlu, 2013:116), and increases employee well-being. Therefore, it is necessary to determine the relationship between employee well-being, burnout and perceived organizational support.

This study aims to evaluate the well-being of employees, burnout and perceived levels of organizational support of employees employed in healthcare institutions and to disclose the relationship between these variables.

\section{MATERIALS AND METHODS}

\section{Purpose of the Study}

This study aims to determine the employee wellbeing, burnout and perceived organizational support levels of healthcare workers and to reveal the relationship between these variables.

\section{Research Hypotheses}

The hypotheses determined for the study's intent are set out below:

$\mathrm{H}_{1}$ : A positive relationship exists between the well-being of the workers and perceived organizational support.
$\mathrm{H}_{2}$ : There is a negative relationship between employee well-being and burnout.

$\mathrm{H}_{3}$ : There is a negative relationship between burnout and perceived organizational support.

\section{Population and Sample}

A total of 450 health-care workers work at Istanbul's Biruni University Hospital, which is the study universe. A simple random sampling method was preferred as the sampling method in the study. The mean and standard deviation> $2.89 \pm 0.47$ according to the organizational support perception values, one of the alternatives based on literature 
knowledge, was calculated according to the $80 \%$ power in the $\mathrm{R}$ program, in a total of 168 individuals' environment. 250 individuals have been reached, 240 of the questionnaires have been returned and assessed accordingly.

\section{Limitations of Research}

The research is limited to the opinions of the individuals included in the sample on the data collection tools of these individuals.

\section{Research Assumptions}

In the analysis, the sample is presumed to represent the world, the data collection tools fulfill the research intent, and the individuals in the sample express accurate and sincere views on the data collection tools.

\section{Data collection tool}

In the research a questionnaire method has been used as a tool for data collection. The questionnaire form consists of four different parts. It includes questions about employee well-being scale, burnout scale, perceived organizational support scale and demographic characteristics. The validity and reliability of the scales used in the research have been proven in previous studies. In the first part of the questionnaire process, questions are asked which decide the participants' demographic characteristics. In the second part, there are expressions to measure employee well-being. In the third part of the study, there are questions to measure the perception of burnout, and in the last part addresses the perception of organizational support.

Employee Well-Being Scale: Employee WellBeing Scale (EWB), which has 18 items developed by Zheng et al. (2015), was used to measure employee well-being. The scale was applied to the Slovak sample in its original English form. Besides, it was translated from English to Turkish Kürşat Ozdasli using the translation-back method to be applied to the Turkish study. Two experts were consulted at Mehmet Akif Ersoy University for both the translation of the scale from English to Turkish and the back translation. There are three dimensions to determine the happiness levels of the employees in the survey. A total of 18 items were included in the questionnaire, which included items 1-6 for life well-being, items 7-12 for workplace well-being, and items 13-18 for psychological well-being. These items were answered by the participants according to the 7-point Likert scale. Participant views have been identified in the form as; 1 - strongly disagree (Strongly disagree), 2Disagree (Disagree), 3-somewhat disagree (Somewhat disagree), 4-I agree with what disagree (Neither agree nor disagree), 5-I agree with a little (Somewhat agree), 6-I agree (Agree) and 7 - strongly agree (Strongly agree). The Cronbach alpha reliability coefficient $(\alpha)$ for employee well-being was determined as 0.85 in the study. The alpha reliability coefficients of Cronbach for sub-dimensions were calculated as well- being for life $(\alpha) 0.79$, well-being for the workplace ( $\alpha)$ 0.84, psychological well-being $(\alpha)$ 0.83. A minimum of 18 points and a maximum of 126 points can be obtained from the Employee Well-Being Scale. The scale is a 7-point Likert type scale. Evaluation of the answers given to the questionnaire 1.00-1.86= Strongly Disagree 1.87-2.71 = Disagree 2.72-3.57 = Slightly Disagree $3.58-4.43=$ Neither agree nor disagree 4.44- 5.29 = Somewhat agree 5.30-6.14 = Agree and 6.15-7 = Strongly Agree .

Burnout: The Burnout Inventory, created by Maslach and Jackson (1981) and included in the Maclach literature, is a 5-point Likert style scale, consisting of 22 objects and 3 sub-dimensions. Among these sub-scales, emotional exhaustion consists of nine items, the depersonalization sub-scale consists of 5 items, and the personal failure sub-scale consists of eight items. Scale items are scored as "1 never" and "5 always". It was translated into Turkish by Ergin (1992). In the study it was found that the Cronbach alpha reliability coefficient $(\alpha)$ for burnout perception is 0.88 . Cronbach's alpha reliability coefficients for the sub-dimensions were determined as emotional exhaustion $(\alpha) 0.89$, depersonalization $(\alpha)$ 0.83, personal failure $(\alpha) 0.86$. The lowest 22 and the highest 60 points can be obtained from the burnout scale. Evaluation of the answers given to the survey questions 1.00-1.80 = Never 1.81-2.60 = Rarely 2.61$3.40=$ Sometimes 3.41-4.20 = Frequently 4.21-5.00= It is always.

Perceived Organizational Support: Perceived Organizational Support Scale (PSSS) developed by Eisenberger et al. (1986) with 36 items. The Cronbach Alpha reliability coefficient of the original 36-point scale was reported as 0.97 . In the same analysis the short forms of the scale consisting of 17 and 8 items were generated considering the high factor structure and reliability coefficients. Within the scope of this study, the 8-item one-dimensional form of AÖDÖ was used (Öztürk, ty tra.Yılmaz, 2016). . The scale contains things such as "The institution for which I work is really concerned about my well-being," "The institution for which I work does not acknowledge the tremendous effort I make." The scale is answered based on a 5-point Likert rating (1: Strongly Disagree, 2: Disagree, 3: Undecided, 4: Agree, 5: Strongly Agree). Items 2, 3, 5 and 7 in the scale are scored in reverse. In the study, the Cronbach alpha reliability coefficient $(\alpha)$ for the perception of organizational support was found to be 0.86 .

\section{Data Analysis}

SPSS 24.0 Statistics software program was used for statistical analysis while analyzing the results obtained in the report. Descriptive statistical methods (frequency, percentage, average, standard deviation) were used when evaluating the study data. Normality tests have been done. It was found that the data were distributed normally. Correlation analysis was conducted to find the relationship between variables. Pearson coefficient was selected as coefficient of 


\section{RESULTS}

\section{Distribution of Demographic Characteristics of Participants}

When analyzing the participants' gender distribution, 82.1 percent are women and 17.9 percent are men. $55.9 \%$ of those participating in the survey are between the ages of $21-26,38.7 \%$ of them between the ages of $27-32,2.6 \%$ of them between the ages of $33-$ 38 , and $2.8 \%$ of them between the ages of 39-44. All participants work at a university hospital. Considering their educational status, $75.5 \%$ of the employees are undergraduate, $10 \%$ of them graduate, $8 \%$ of them high school and $6.5 \%$ of them doctorate graduate. $62.8 \%$ of the participants are nurses, $21.2 \%$ of them are administrative employees and $15 \%$ of them are medical secretaries. When the total term of office is examined, $55.9 \%$ of the employees' terms are between $0-5$ years, $37.8 \%$ are between $6-10$ years, and $6.3 \%$ are between $11-15$ years. When the duration of working in their hospital is examined, all of the participants are between 0-5 years. When the weekly working hours of the participants are examined, $44.5 \%$ of the employees are between $40-50$ hours, $35.8 \%$ are between $30-40$ hours, and $19.7 \%$ are between $50-60$ hours. $74.7 \%$ of the participants work continuously during the day and $25.3 \%$ work in shifts. $76.6 \%$ of the participants voluntarily chose the department they work in while $23.4 \%$ didn't choose it voluntarily.

Table 1. Cronbach Alpha Values of the Scales

\begin{tabular}{lr}
\hline & $\begin{array}{r}\text { Cronbach' } \\
\text { s Alpha }\end{array}$ \\
\hline Employee Wellbeing Scale & 0.85 \\
Well-being of Life & 0.79 \\
Workplace Wellbeing & 0.84 \\
Psychological Well-being & 0.83 \\
Burnout Scale & 0.88 \\
Emotional Burnout & 0.89 \\
Depersonalization & \\
Personal Failure & 0.86 \\
Perceived Organizational Support & 0.86 \\
\hline
\end{tabular}

Table 3. Correlation Values Between Employee Wellbeing, Burnout, Perceived Organizational Support and Its Sub-Dimensions

\begin{tabular}{|c|c|c|c|c|c|c|c|c|c|}
\hline & 1 & 2 & 3 & 4 & 5 & 6 & 7 & 8 & 9 \\
\hline Employee Wellbeing $^{1}$ & 1 & - & - & - & - & - & - & - & - \\
\hline Well-being of Life ${ }^{2}$ & $0,772 * *$ & 2 & - & - & - & - & - & - & - \\
\hline Workplace Wellbeing $^{3}$ & $0,685 * *$ & $0.782 * *$ & 3 & - & - & - & - & - & - \\
\hline Psychological Well-being ${ }^{4}$ & $0.763 * *$ & $0.687 * *$ & $0.785 * *$ & 4 & - & - & - & - & - \\
\hline Burnout Scale $^{5}$ & $-0,675 * *$ & $-0,682 * *$ & $-0.615^{* *}$ & $-0,677 * *$ & 5 & - & - & - & - \\
\hline Emotional Burnout $^{6}$ & $-0,662 * *$ & $-0,628 * *$ & $-0,635 * *$ & $-0.645^{* *}$ & $0.725 * *$ & 6 & - & - & - \\
\hline Desensitization $^{7}$ & $-0,641 * *$ & $-0.681 * *$ & $-0,626 * *$ & $-0,648 * *$ & $0,695 * *$ & $0,728 * *$ & 7 & - & - \\
\hline Personal Failure $^{8}$ & $-0,663 * *$ & $-0,677 * *$ & $-0,682 * *$ & $-0,695 * *$ & $0,728 * *$ & $0,741 * *$ & $0.762 * *$ & 8 & - \\
\hline Perceived Organizational Support $^{9}$ & $0.775 * *$ & $0,768^{* *}$ & $0.755^{* *}$ & $0,743 * *$ & $-0,563 *$ & $-0.557^{*}$ & $-0,518 *$ & $-0,595 *$ & 9 \\
\hline
\end{tabular}

$\mathrm{N}=240, * * \mathrm{p}<0.01, * \mathrm{p} 0.05$

When analyzing the correlation analysis to assess the relationship between the variables, a solid, negative and opposite association between employee well-being and burnout was found $\left(\mathrm{r}=-0.675^{* *}\right.$
Cronbach Alpha values are as above. Cronbach Alpha values $(\alpha=0.85)$ of the employee goodness scale and Cronbach Alpha values of its lower dimensions were found to be $(\alpha=0,79, \alpha=0,84, \alpha=0,83)$, respectively. Cronbach alpha values of the subdimensions of the burnout scale $(\alpha=0.88)$ were determined as $(\alpha=0.89, \alpha=0.83, \alpha=0.86)$ respectively, and the Cronbach Alpha value of the perceived organizational support scale $(\alpha=0.86)$.

Table 2. Descriptive Statistics Regarding the Scale and Sub-Dimensions

\begin{tabular}{lrrr}
\hline & $\mathbf{N}$ & $\overline{\mathbf{x}}$ & $\mathbf{S s}$ \\
\hline Employee Wellbeing Scale & 240 & 4,15 & 1,05 \\
Well-being of Life & 240 & 4,32 & 0.85 \\
Workplace Wellbeing & 240 & 4,22 & 0.80 \\
Psychological Well-being & 240 & 3,90 & 1,18 \\
Burnout Scale & 240 & 3,71 & 0,75 \\
$\quad$ Emotional Burnout & 240 & 3,65 & 0,64 \\
Depersonalization & 240 & 3,81 & 0,82 \\
$\quad$ Personal Failure & 240 & 3,67 & 0,68 \\
Perceived Organizational & 240 & 3,63 & 1,02 \\
Support Scale & & & \\
\hline
\end{tabular}

When reviewing Table 2 it was found that the average scale of well-being scores for workers was (4.15) and the average of their sub-dimensions was (4.32), (4.22), (3.90), respectively. The overall burnout scale scores were found to be (3.71), the subdimensions overall as (3.65), (3.81), (3.67), respectively, and the perceived organizational support scale scores average (3.63). 
found between burnout and perceived organizational $\quad$ support $(\mathrm{r}=-0.563 * \mathrm{p}<0.05)$.

\section{DISCUSSION}

Today, most of the employees working in health institutions experience burnout syndrome. Burnout syndrome is a negative situation that harms the person and reduces the quality of the service provided by the health worker. Healthcare staff do not suffer burnout and feel good in terms of life, job and psychological aspects for the effectiveness and productivity of healthcare institutions and the quality of service rendered by healthcare professionals. For this, the organization should support its employees, and they should make their employees feel that they stand by the organization. If the workers feel they are supporting their company, they may also improve the quality of the service they offer.

Jawahar et al. (2007: 149), in their study on a sample of 120 employees, found a negative, inverse relationship between perceived organizational support and burnout to support our study. Bobbio et al. (2012: 80 ) in a study conducted with nurses to determine the relationship between perceived organizational support and burnout levels, they found that there is a negative, opposite relationship between perceived organizational support and burnout in a way that supports our study. As perceived organizational support increases, burnout perception decreases, and as burnout perception increases, perceived organizational assistance decreases.

Louise et al. (2016: 6), in their study conducted by healthcare workers to determine the relationship between burnout and well-being levels, also found a negative, opposite and strong relationship between well-being and burnout, supporting our study. Accordingly, as the perception of burnout increases, the well-being decreases.

Genc E. (2018), in her study, it was found that there is a negative relationship between perceived organizational support and burnout. Burnout decreases as the perceived perception of organizational support among employees increases. This conclusion is same as our research' conclusion.

Walters and Raybould. (2007), In their study, it was found that there is a negative relationship between burnout and organizational support. Burnout decreases as the perceived perception of organizational support among employees increases. This conclusion is same as our research' conclusion.

\section{CONCLUSIONS}

According to the results of this research, a strong, positive, same-directional relationship was found between employee well-being and perceived organizational support $(\mathrm{r}=0.775 * *)$. This situation shows that employee well-being is also growing as awareness of organizational support rises. According to this result, $\mathrm{H} 1$ hypothesis has been accepted. A strong, negative and opposite relationship was found between employee well-being and burnout $(r=-0.675$ **). Accordingly, it shows that the sense of burnout decreases as the awareness of employee well-being increases. According to this result, $\mathrm{H} 2$ hypothesis has been accepted. A negative and opposite relationship was found between burnout and perceived organizational support $(\mathrm{r}=0.563 *)$. As the perception of organizational assistance declines, the burnout experience rises accordingly. According to this result, H3 hypothesis has been accepted.

According to these findings, high perceptions of well-being and organizational support of employees decrease burnout syndrome. Thus, employees can do their jobs better. This is very important for the quality of healthcare services. Because there is no compensation for health services. Therefore, burnout syndrome should not be in healthcare workers.

With this study, health managers should be more careful about reducing burnout syndrome of healthcare workers. It is very important in terms of the literature to find out that employee well-being and perceived organizational support reduce burnout syndrome. Thus, managers can take initiatives to reduce the burnout syndrome of employees by using this information.

For the quality of the service provided to individuals who want to receive health care and the Health employee's health, there should be no burnout syndrome. Burnout syndrome lowers the quality of health workers' service and affects the employee himself. Employee health is very critical for service quality and the employee himself. For this, managers working in health institutions should inspire their workers:

- Reduce or destroy the resources that can induce burnout syndrome,

- Make them believe they are with their workers and their employees are important for the organization.

- Identifying sources of employee well-being and using them for employees.

- Organizing in-service trainings for employees

- Provide career consultancy services to employees

Employee well-being, burnout and perceived organizational support levels of the participants were determined in line with the subject determined in the study and the relationship between them was determined. According to the results of the research, a strong, negative, and the opposite relationship between employee well-being and burnout, a strong, 
positive, and same direction between employee wellbeing and perceived organizational support, a moderate, negative and opposite relationship between burnout and perceived organizational support.

According to the results, a relationship is thought to exist between employee well-being, burnout and perceived variables of organizational support and other variables. Therefore, the relationship of different variables can be explored in future studies on these three variables and can contribute to the literature on this topic.

\section{REFERENCES}

Ali, D. (2020). The Effect Of Burnout On The Job Satisfaction Of Salespeople. Istanbul: Bahcesehir University.

Bacaksız, F. E. (2016). Örgütsel Erdemliliğin Hemşirelerin Örgütle Özdeşleşme Düzeylerine ve Performanslarına Etkisi: Algılanan Örgütsel Desteğin Aracı Rolü. Doktora Tezi. Istanbul: Istanbul Universitesi.

Balcığlu, İ., Mehmetali, S., \& Rozant, R. (2008). Tükenmişlik Sendromu. Dirim Tip Gazetesi, 83(1), 99-104.

Bobbio, A., Bellan, M., \& Manganelli, A. M. (2012). Empowering leadership, perceived organizational support, trust, and job burnout for nurses: A study in an Italian general hospital. Healthcare Management Review, 37(1), 77-87.

Demirel, E. (2013). Mesleki Stresin İş Tatminine Etkisi: Örgütsel Desteğin Aracılık Rolü. Niğde Üniversitesi Íktisadi ve İdari Bilimler Dergisi, 6(1), 220-241.

Eisenberger, R., Huntington, R., Hutchison, S., \& Sowa, D. (1986). Perceived organizational support. Journal of Applied Psychology, 71(3), 500-507.

Hall, L., Johnson, J., Ian, W., \& Tsipa, A. (2016). Healthcare Staff Wellbeing, Burnout and Patient Safety: A Systematic Review. Plos One, 1-12.

Kaplan, M., \& Öğüt, A. (2012). Algılanan Örgütsel Destek ile Örgütsel Bağlılık Arasındaki İlişkinin Analizi: Otel İşletmelerinde Bir Uygulama. Süleyman Demirel Üniversitesi Iktisadi ve İdari Bilimler Dergisi, 17(1), 387-401.

Keles, D., \& Goktepe, E. A. (2020). The Effect of Emotional Labor Behaviors of Employees on Burnout Syndrome and Intention to Quit: A Research in the Ready-made Clothing Sector. Business and Economic Research Journal, 3(11), 855-873.
Martic, K. (2020, Haziran 30). What Is Employee Wellbeing and How to Launch a Wellbeing Program. Retrieved from https://blog.smarp.com/employee-wellbeing-definition-importancebest-practice

Maslach, C., \& Jackson, S. (1981). The Measurement of Experienced Burnout. Journal of Occupational Behaviour, 2(1), 99113.

Maslach, C., Schaufeli, W. B., \& Leiter, M. B. (2001). Job burnout. Annual Review of Psychology, 52(1), 397-422.

Özdevecioğlu, M. (2003). Algılanan Örgütsel Destek ile Örgütsel Bağlılık Arasındaki İlişkilerin Belirlenmesine Yönelik Bir Araştırma. Dokuz Eylül Üniversitesi İktisadi ve İdari Bilimler Fakültesi Dergisi, 18(2), 113-130.

Özdevecioğlu, M. (2003). Algılanan Örgütsel Destek İle Örgütsel Bağlılık Arasındaki İlişkilerin Belirlenmesine Yönelik Bir Araştırma. Dokuz Eylül Üniversitesi İ.I.B.F Dergisi, 18(2), 113-130.

Short, S. (2018, Şubat 5). What is employee what is employee wellbeing? ellbeing? Retrieved from What is employee wellbeing?: https://face2facehr.com/what-is-employee-wellbeing/

Tuğrul, B., \& Çelik, E. (n.d.). Normal Çocuklarla Çalışan Anaokulu Öğretmenlerinde Tükenmişlik. Pamukkale Üniversitesi Eğitim Fakültesi Dergisi, 12, 1-11.

Walters, G., \& Raybould, M. (2007). Burnout and Perceived Organisational Support Among Front-Line Hospitality Employees. Journal of Hospitality and Tourism Management, 14(2), 144-156.

Zheng, X., Zhu, W., Zhao, H., \& Zhang, C. (2015). Employee Well-Being in Organizations: Theoretical Model, Scale Development, And Cross-Cultural Validation. Journal of Organizational Behavior, 5(36), 621-644. 